Widya Akuntansi dan Keuangan

Universitas Hindu Indonesia

Edisi Agustus 2019, ISSN 2655-9498

\title{
ANALISIS PENGUKURAN KINERJA DENGAN PENDEKATAN
}

\author{
VALUE FOR MONEY
}

\section{Rai Dwi Andayani W}

Universitas Hindu Indonesia, e mail: dwiandayani63@yahoo.com

\begin{abstract}
This research intends to determine the performance of irrigation physical activiies of Badung Regency in 2018 based on: 1) economy ratio, 2) efficiency ratio, and (3)effectiveness ratio. This research is a descriptive by analyzing progress report of Irrigation project in Badung Regency in 2018. Data collection method is documentation and Data analysis tool is value for money concept. The results of the research concludes that the performance of Public Work Office on irrigation physical activity in Badung Regency in 2018 has been: 1) economically with economy ratio averagely under 100\%; 2) efficiently conducted with efficiency averagely under $100 \% ; 3)$ effectively conducted with effectivenessration of $100 \%$ in average.
\end{abstract}

Keywords: economy, efficiency, and effectiveness

\section{PENDAHULUAN}

Di jaman era globalisasi masa kini kesadaran masyarakat yang semakin cerdas dan kritis terhadap penyelenggaraan pembangunan yang menuntut dilakukannya transparansi dan akuntabilitas Publik. Kinerja keuangan merupakan suatu hal yang sangat penting untuk dikaji dalam organisasi sektor publik termasuk pemerintahan, sejak diterapkannya penganggaran berbasis kinerja, semua pemerintah dituntut untuk mampu menghasilkan kinerja keuangan pemerintah dengan baik. Semakin meningkatnya tuntutan pelaksanaan akuntabilitas publik oleh organisasi sektor publik seperti pemerintah pusat dan daerah, unit-unit kerja pemerintah, departemen dan lembaga negara diharapkan dapat mengurangi terjadinya pemborosan, kebocoran dana dan mendeteksi program-program yang tidak layak. Salah satu hal yang dapat dijadikan alat untuk menilai pertanggungjawaban di instansi pemerintah dengan melihat kinerja keuangannya melalui perhitungan dan analisis pencapaian target dan realisasi dari penerimaan dan pengeluaran atas Anggaran Pendapatan dan Belanja Negara (APBN), baik dari sisi input, output, outcome, impact, dan benefit yang didapatkan. Penilaian kinerja keuangan sangatlah penting dilaksanakan untuk mengetahui mampukah suatu instansi melaksanakan program 
Widya Akuntansi dan Keuangan

Universitas Hindu Indonesia

Edisi Agustus 2019, ISSN 2655-9498

kerjanya dengan baik. Dalam menilai kinerja keuangannya, diharapkan agar mampu memperhatikan Value For Money dalam menjalankan aktivitasnya.

Organisasi sektor publik sering dijadikan sebagai sarang pemborosan, sumber kebocoran dana, dan institusi yang selalu mengalami kerugian. Tuntutan masyarakat ini sesuai dengan UU No. 22 Tahun 1999 dan UU No. 25 Tahun 1999 yang digunakan sebagai dasar bagi serangkaian reformasi kelembagaan untuk menciptakan good governance, yaitu pemerintahan yang bersih, ekonomis, efektif, transparan, responsif, dan akuntabel. Transparansi dan akuntabilitas dalam organisasi sektor publik harus memperhatikan value for money dalam menjalankan aktivitasnya. Value for money merupakan konsep pengelolaan organisasi sektor publik yang mendasarkan pada tiga elemen utama, yaitu ekonomi, efisiensi, dan efektivitas (Mardiasmo, 2009). Ruang lingkup ekonomi meliputi pemerolehan input dengan kualitas dan kuantitas tertentu pada harga yang terendah. Efisien mengenai pencapaian output yang maksimum dengan input tertentu, sedangkan efektivitas berkaitan erat terhadap tingkat pencapaian hasil program dengan target yang ditetapkan. Tujuan yang diinginkan oleh masyarakat mencakup pertanggungjawaban mengenai pelaksanaan Value for Money, yaitu: ekonomis (hemat cermat) dalam pengadaan dan alokasi sumber daya, efisien (berdaya guna) dalam penggunaan sumber daya dalam arti penggunaannya diminimalkan dan hasilnya dimaksimalkan, serta efektif (berhasil guna) dalam arti mencapai tujuan dan sasaran.

Akuntabilitas publik sesuai dengan karakteristik pelaksanaan good governance yang diberikan oleh United Nation Development Program dalam Mardiasmo (2009), meliputi partisipasi, penegakan hukum, transparansi, daya tanggap, orientasi kepentingan umum, kesetaraan, efisiensi dan efektivitas, akuntabilitas, dan visi ke depan. Dalam organisasi sector public, akuntabilitas publik yaitu pemberian informasi kepada publik dan konstituen lainnya yang menjadi pemangku kepentingan (stakeholder) (Mahmudi, 2007). Akuntabilitas bukan hanya sekedar kemampuan bagaimana uang publik tersebut telah dibelanjakan, tetapi meliputi kemampuan yang menunjukkan bahwa uang publik tersebut telah dibelanjakan secara ekonomis, efektif, dan efisien. Dalam akuntabilitas publik juga terkait dengan kewajiban dalam menjelaskan dan menjawab pertanyaan mengenai apa yang telah, sedang, dan direncanakan akan dilaksanakan oleh setiap organisasi publik. Hasil pengukuran metode Value for Money 
terdapat tiga elemen utama yang dinilai yaitu ekonomi, efisiensi, dan efektivitas. Value for Money merupakan inti pengukuran kinerja keuangan pada organisasi sektor publik karena kinerja pemerintah tidak bisa dinilai hanya dari output yang dihasilkan, tetapi secara harus mempertimbangkan input, output, dan outcome secara bersama-sama.

Dinas Pekerjaan Umum di Kabupaten Badung merupakan salah satu organisasi sektor publik, dalam salah satu programnya diantaranya meningkatkan perekonomian dan kesejahteraan masyarakat. Dinas Pekerjaan Umum di Kabupaten Badung belum dapat bekerja secara maksimal karena masih banyaknya hambatan yang dihadapi dan masih cukup banyak keluhan yang disampaikan oleh masyarakat. Keluhan tersebut diantaranya seperti belum meratanya perbaikan infrastruktur yang menunjang masyarakat di pedesaan. Berdasarkan hasil observasi salah satu penyebabnya adalah belum adanya saluran irigasi yang permanen sehingga air banyak yang menyerap kembali ketanah, selain itu ada juga sebagian masyarakat yang membobol saluran air irigasi tanpa sepengetauhan Petugas Petani Pengguna Air (P3A), sehingga air tidak sampai di sawah maupun ladang. Ini menyebabkan banyak lahan pertanian yang berubah fungsi, diantaranya berubah menjadi area perumahan. Banyaknya beberapa permasalahan dan keluhan ini mengindikasikan bahwa pelayanan yang diberikan Dinas Pekerjaan Umum di Kabupaten Badung perlu untuk pengadakan pekerjaan fisik berupa pembuatan saluran irigasi ke sawah maupun ladang para petani yang berada di desa dan kelurahan yang letaknya $+5 \mathrm{~km}$ dari Kabupaten Badung. Sehubungan dengan hal tersebut, maka Dinas Pekerjaan Umum di Kabupaten Badung memerlukan adanya pengukuran kinerja kegiatan fisik untuk mengetahui kinerja kegiatan fisik secara keseluruhan dalam melaksanakan program kerjanya.

Kinerja kegiatan fisik Dinas Pekerjaan Umum di Kabupaten Badung sering dinilai hanya dari aspek input dan output. Instansi ini dinilai cukup berhasil jika bisa menyerap anggaran 100\% (input) dan melaksanakan program tahunan (output), tanpa ada penilaian terhadap aspek hasil (outcome), manfaat (benefit), dan juga dampak (impact). Oleh karena itu diperlukan ukuran nonfinansial dalam pengukuran kinerja kegiatan fisik berbasis konsep value for money pada kegiatan fisik pekerjaan Dinas Pekerjaan Umum di Kabupaten Badung. Beberapa masalah inilah yang menjadi latar belakang penelitian ini diteliti kembali, sehingga 
penulis bermaksud untuk melakukan penelitian dengan judul analisis pengukuran kinerja keuangan dengan pendekatan value for money (study pada Dinas Pekerjaan Umum di Kabupaten Badung).

\section{METODE PENELITIAN}

Berdasarkan karakteristik masalah, penelitian ini termasuk ke dalam penelitian deskriptif. Penelitian deskriptif (descriptive research) merupakan penelitian masalah-masalah berupa fakta-fakta saat ini dari suatu populasi (Nur Indriantoro dan Bambang Supomo, 2009). Pada umumnya penelitian deskriptif merupakan penelitian non hipotesis, sehingga dalam langkah penelitiannya tidak perlu merumuskan hipotesis. Menurut proses, sifat dan analisis datanya penelitian ini tergolong penelitian deskriptif yang bersifat eksploratif, yang bertujuan untuk menggambarkan keadaan atau status fenomena (Suharsimi Arikunto, 1997). Tujuan penelitian deskriptif ini adalah untuk menjawab pertanyaan yang berkaitan dengan keadaan tertentu dari subjek yang diteliti dan untuk mendapatkan informasi mengenai hasil pengukuran kinerja kegiatan fisik perbaikan infrastruktur Dinas Pekerjaan Umum di Kabupaten Badung dengan menggunakan analisis Value for Money. Penelitian ini dilakukan pada Dinas Pekerjaan Umum di Kabupaten Badung yang beralamatkan di Sempidi, dengan waktu penelitian dilakukan selama 3 (tiga) bulan yaitu mulai Bulan Januari sampai dengan bulan April 2019.

Subjek dalam penelitian ini adalah Pemerintah Kabupaten Badung dan pelaporan Pemerintah Kabupaten Badung, sedangkan objek penelitian ini adalah data laporan bulanan kemajuan pekerjaan Tahun 2018. Informan Kunci yaitu Kepala Dinas Pekerjaan Umum di Kabupaten Badung, karena yang mengetahui dan memiliki informasi pokok yang diperlukan dalam penelitian ini, dan Informan Pendukung yaitu Kepala Seksi dan Pengawas Lapangan, karena mereka yang terlibat secara langsung dalam kegiatan fisik perbaikan infrastruktur Dinas Pekerjaan Umum di Kabupaten Badung.

Variabel dalam penelitian ini adalah Value for Money. Value for Money merupakan konsep pengukuran kinerja kegiatan fisik perbaikan infrastruktur yang berdasarkan pada tiga elemen yaitu ekonomi, efisiensi, dan efektivitas. 


\section{Ekonomi}

Ekonomi adalah hubungan antara pasar dan input. Ekonomi terkait dengan sejauh mana kegiatan fisik pekerjaan perbaikan infrastruktrur dapat meminimalkan input yang digunakan dengan menghindari pengeluaran yang boros dan tidak produktif.

\section{Efisien}

Efisiensi adalah hubungan antara input dan output. Efisien dalam penggunaan sumber daya berarti penggunaannya diminimalkan dan hasilnya dimaksimalkan (maximing benefits and minimizing costs). Proses kegiatan operasional dapat dikatakan efisien apabila suatu produk atau hasil kerja tertentu dapat dicapai dengan penggunaan sumber daya dan dana yang serendah-rendahnya (spending well). Pengertian yang hampir sama antara efisien dengan ekonomi karena keduanya menghendaki penghapusan dan penurunan biaya.

\section{Efektivitas}

Efektivitas adalah hubungan antara output dan tujuan yang telah ditetapkan. Kegiatan operasional dapat dikatakan efektif apabila proses kegiatan tersebut mencapai tujuan dan sasaran akhir kebijakan.

\section{Input}

Input adalah sumber daya yang digunakan untuk pelaksanaan suatu kebijakan, kegiatan/ program dan aktivitas.

\section{Output}

Output adalah hasil, tujuan atau target yang hendak dicapai dari suatu kegiatan/progam.

\section{Outcome}

Outcome adalah dampak suatu program atau kegiatan terhadap masyarakat atau mengukur kualitas output terhadap dampak yang dihasilkan.

Jenis data yang dianalisis pada penelitian ini menggunakan dua data yaitu:

1. Data kualitatif, yaitu data yang diperoleh berupa keterangan-keterangan yang mendukung penulisan ini yang diperoleh dari hasil wawancara, maupun dokumen/arsip organisasi berupa gambaran umum organisasi, dan srtuktur organisasi 
2. Data kuantitatif, yaitu data yang berupa angka-angka yang dapat diperoleh melalui dokumen organisasi seperti data laporan bulanan kemajuan pekerjaan. Sedangkan sumber data peneliti menggunakan data sekunder, yaitu data yang diambil dari laporan bulanan kemajuan pekerjaan.

Teknik pengumpulan data yang digunakan dalam penelitian ini yaitu:

1. Teknik wawancara merupakan pengumpulan data dengan mengajukan pertanyaan langsung kepada Kepala Dinas Pekerjaan Umum di Kabupaten Badung.

2. Teknik dokumentasi merupakan suatu teknik pengumpulan data dengan cara mengumpulkan dokumen - dokumen organisasi yang berkaitan dengan penelitian yang dilakukan. Cara memperoleh data pada teknik ini adalah data mengenai rencana dan realisasi pekerjaan irigasi Dinas Pekerjaan Umum di Kabupaten Badung.

3. Studi Pustaka Penulis mempelajari literatur-literatur tentang hal-hal yang menyangkut penelitian ini.

Teknik analisis data yang digunakan dalam penelitian ini adalah menggunakan value for money yaitu suatu analisis yang menilai kinerja suatu entitas dari suatu segi ekonomi, efesiensi, dan efektivitas. Berikut ini teknik analisis data yang digunakan pada masing-masing elemen.

1. Pengukuran Ekonomi

Ekonomi memiliki pengertian bahwa dalam memperoleh sumber daya (input) sebaiknya dengan kualitas dan kuantitas tertentu pada harga yang lebih rendah (spending less) atau harga yang mendekati harga pasar.

Ekonomi merupakan perbandingan input dengan harga input dengan perhitungan sebagai berikut:

$$
\text { Ekonomis }=\frac{\text { Input }}{\text { Harga Input }} \times 100 \%
$$

Keterangan:

Input : dana realisasi yang digunakan

Harga Input : dana anggaran yang dianggarkan 
Kinerja suatu kegiatan fisik pekerjaan irigasi dikatakan ekonomis apabila input lebih kecil dari pada Harga Input, artinya bahwa dana realisasi yang digunakan lebih kecil dari anggaran yang telah dianggarkan dengan kata lain kegiatan tersebut dapat menghemat atau mengurangi biaya yang tidak diperlukan dan tidak ada pemborosan.

Kriteria ekonomi adalah:

- Jika diperoleh nilai kurang dari $100 \%$ berarti ekonomis

- Jika diperoleh nilai sama dengan $100 \%$ berarti ekonomi seimbang

- Jika diperoleh nilai lebih dari $100 \%$ berarti tidak ekonomis.

2. Pengukuran Efisiensi

Efisiensi merupakan pencapaian output yang maksimal dengan input tertentu atau penggunaan input yang rendah untuk mencapai output tertentu.

Secara matematis, rumus efisiensi dapat dihitung dengan menggunakan rumus sebagai berikut:

$$
\text { Efisiensi }=\frac{\text { Input }}{\text { Output }} \times 100 \%
$$

Keterangan :

$$
\begin{array}{ll}
\text { Output } & : \text { hasil yang dicapai } \\
\text { Input } & : \text { dana realisasi yang digunakan }
\end{array}
$$

Kinerja kegiatan fisik pekerjaan irigasi dikatakan efisien apabila output lebih besar dari pada Input, artinya bahwa dengan dana realisasi yang disediakan bisa menghasilkan output yang lebih besar dengan kata lain suatu produk atau hasil kerja tertentu dapat dicapai dengan menggunakan sumber daya dan dana yang serendah-rendahnya.

Kriteria efisiensi adalah:

- Jika diperoleh nilai kurang dari $100 \%$ berarti efisiens

- Jika diperoleh nilai sama dengan $100 \%$ berarti efisiensi seimbang

- Jika diperoleh nilai lebih dari $100 \%$ berarti tidak efisiens.

3. Pengukuran Efektivitas

Pengukuran efektivitas merupakan pencapaian hasil program dengan target yang telah ditetapkan. 
Kinerja efektivitas suatu kegiatan fisik pekerjaan irigasi dapat dihitung dengan menggunakan rumus sebagai berikut:

$$
\text { Efektivitas }=\quad \frac{\text { Outcome }}{\text { Output }} \times 100 \%
$$

Keterangan:

Outcome : tujuan atau target yang hendak dicapai

Output : hasil yang dicapai

Suatu kinerja kegiatan fisik pekerjaan irigasi dikatakan efektif apabila output lebih besar dari pada outcome, artinya bahwa hasil yang dicapai bisa melebihi dari tujuan atau target yang hendak dicapai.

Kriteria efektivitas adalah:

- Jika diperoleh nilai kurang dari $100 \%$ berarti tidak efektif

- Jika diperoleh nilai sama dengan $100 \%$ berarti efektivitas seimbang

- Jika diperoleh nilai lebih dari $100 \%$ berarti efektif.

\section{HASIL DAN PEMBAHASAN}

\section{Hasil}

Value for Money merupakan variabel utama dalam penelitian ini. Value for Money adalah metode untuk mengukur kinerja kegiatan fisik pekerjaan irigasi Kabupaten Badung. Data yang diambil pada Dinas Pekerjaan Umum di Kabupaten Badung adalah laporan kemajuan pekerjaan irigasi Kabupaten Badung Tahun 2018. Laporan kemajuan pekerjaan irigasi Kabupaten Badung Tahun 2018 adalah suatu bentuk laporan yang berisi informasi kemajuan pekerjaan irigasi Kabupaten Badung Tahun 2018 dalam mencapai tujuan dan sasaran strategis dari suatu kegiatan pekerjaan di Dinas Pekerjaan Umum di Kabupaten Badung.

Deskripsi Pekerjaan Fisik Irigasi Kabupaten Badung merupakan pekerjaan-pekerjaan yang bertalian dengan usaha mendapatkan air untuk sawah, ladang, perkebunan dan usaha pertanian. Usaha tersebut terutama menyangkut pembuatan sarana dan prasarana untuk membagi-bagikan air ke sawah-sawah secara teratur dan membuang air kelebihan yang tidak diperlukan lagi untuk memenuhi tujuan pertanian. Pekerjaan irigasi tersebut berada di lokasi 
Widya Akuntansi dan Keuangan

Universitas Hindu Indonesia

Edisi Agustus 2019, ISSN 2655-9498

desa Baha Jadi yang sumber pendanaanya diperoleh dari Pusat dan Daerah yaitu Dana Alokasi Khusus (DAK) dan Pendapatan Asli Daerah dengan panjang saluran irigasi 1.788,00 m'. Adapun dana anggaran yang di gunakan dapat dilihat pada tabel sebagai berikut:

Tabel 1. Dana Anggaran Pekerjaan Irigasi Kabupaten Badung 2018

\begin{tabular}{c|l|r|r|r}
\hline No & \multicolumn{1}{|c|}{ Uraian } & Volume & Satuan & \multicolumn{1}{c}{ Anggaran (Rp) } \\
\hline I & Pekerjaan Persiapan & & & 100,00 \\
1 & Pengukuran Pematokan & 1,00 & Ls & $2.000 .000,00$ \\
2 & Papan Nama Kegiatan & 1,00 & Ls & $300.000,00$ \\
II & Pekerjaan Tanah & 625,00 & $\mathrm{M}^{2}$ & $34.550 .000,00$ \\
1 & Galian Tanah & 98,00 & $\mathrm{M}^{2}$ & $1.956 .000,00$ \\
2 & Urugan Tanah Kembali & & & \\
III & Pekerjaan Pasangan & 585,00 & $\mathrm{M}^{2}$ & $451.457 .890,00$ \\
1 & Pasangan Batu Kali & $2.956,00$ & $\mathrm{M}^{2}$ & $115.934 .748,00$ \\
2 & Plesteran & $2.956,00$ & $\mathrm{M}^{2}$ & $73.456 .000,00$ \\
3 & Acian & & & \\
IV & Pekerjaan Lain-lain & 1,00 & Ls & $650.000,00$ \\
1 & Pekerjaan Akhir & & $64.845 .000,00$ \\
\hline & Pajak PPN & & $745.149 .638,00$ \\
\hline
\end{tabular}

Sumber : Dokumen Dinas PU Kabupaten Badung 2018

Pekerjaan fisik irigasi Kabupaten Badung merupakan pekerjaan-pekerjaan yang meliputi:

1. Pekerjaan Persiapan sebagai berikut:

Pengukuran/pematokan adalah pekerjaan awal yang berupa tanda dimana pekerjaan akan dimulai dan diakhiri. Dengan dipasangnya patok setiap patok sejauh seratus meter agar diketahui sudah berapa jarak pekerjaan yang sudah dikerjakan.

Papan nama kegiatan merupakan sebagai tanda pengenal dari suatu pekerjaan dimana papan nama kegiatan tersebut tertera nama kegiatan, nama pelaksana, dana kegiatan, panjang kegiatan dan waktu pelaksanaan.

2. Pekerjaan tanah sebagai berikut:

Galian tanah merupakan pekerjaan yang dilaksanakan dengan membuat lubang di tanah sesuai perencanaan tertentu untuk keperluan saluran irigasi untuk petani.

3. Urugan tanah kembali merupakan Urugan tanah adalah suatu jenis pekerjaan yang bertujuan untuk memindahkan tanah (padas, merah atau semi padas) dari satu tempat 
lokasi (sumber pengambilan tanah) ke tempat lokasi lain yang di inginkan sebanyak yang dibutuhkan agar tercapai bentuk dan ketinggian tanah yang di inginkan, antara lain sektor pertanian (irigasi sawah, ladang dan perkebunan), infrastruktur pembangunan (pondasi bangunan) dan kerajinan (gerabah, tembikar, pot, genteng dan batu bata).

4. Pekerjaan Pasangan sebagai berikut:

Pekerjaan Pasangan batu kali merupakan jenis pekerjaan yang strukturnya terbuat dari pasangan batu kali yang disusun sedemikian rupa sehingga berdiri kokoh bahkan mampu untuk mendukung beban dinding batu bata rumah atau pagar diatasnya. Pasangan batu kali tersusun dari batu kali, pasir yang di rekatkan dengan semen pc, adapun komposisi semennya bermacam-macam.

Pekerjaan plesteran merupakan penutup dinding yang terdiri dari bahan semen (semen Portland/PC) dan pasir pasangan. Permukaan dinding batu kali dapat ditutup dengan plesteran di bagian luarnya.

Pekerjaan acian adalah campuran antara semen PC dengan air saja, pekerjaan acian semen pada saluran irigasi merupakan langkah akhir dari rangkaian pemasangan dinding,

5. Pekerjaan lain-lain sebagai berikut: Pekerjaan akhir atau disebut juga pekerjaan finishing adalah pekerjaan akhir dari sebuah pekerjaan saluran irigasi dalam rangka menutupi, melapisi dan memperindah dari sebuah bangunan atau konstruksi tersebut.

Penelitian ini mendiskripsikan bagaimana mengukur kinerja kegiatan fisik pekerjaan irigasi pada Dinas Pekerjaan Umum Kabupaten Badung Tahun 2018 menggunakan tiga rasio yang diteliti yaitu ekonomi, efisiensi, dan efektivitas. Berikut ini analisis data yang digunakan pada masing-masing rasio:

1. Rasio Ekonomi Ekonomi memiliki pengertian bahwa dalam memperoleh sumber daya (input) sebaiknya dengan kualitas dan kuantitas tertentu pada harga yang lebih rendah (spending less) atau harga yang mendekati harga pasar. Ekonomi merupakan perbandingan input dengan input value yang dinyatakan dalam satuan moneter. Kinerja suatu kegiatan fisik pekerjaan irigasi dikatakan ekonomis apabila input lebih kecil dari 
Widya Akuntansi dan Keuangan

Universitas Hindu Indonesia

Edisi Agustus 2019, ISSN 2655-9498

pada Harga Input, artinya bahwa dana realisasi yang digunakan lebih kecil dari anggaran yang telah dianggarkan.

Berikut ini adalah Tabel mengenai pengukuran ekonomi kegiatan fisik pekerjaan irigasi pada Dinas Pekerjaan Umum Kabupaten Badung Tahun 2018:

Tabel 2. Pengukuran Rasio Ekonomi Pada Pekerjaan Irigasi Kabupaten Badung

\begin{tabular}{l|l|r|r|r|r|r}
\hline No & \multicolumn{1}{|c|}{ Uraian } & \multicolumn{1}{c|}{$\begin{array}{c}\text { Anggaran } \\
\text { (Rp) }\end{array}$} & Realisasi (Rp) & $\begin{array}{c}\text { Ekonomi } \\
(\%)\end{array}$ & $\begin{array}{c}\text { Penghematan } \\
(\mathbf{R p})\end{array}$ & $\begin{array}{c}\text { Output } \\
(\%)\end{array}$ \\
\hline 1 & Pengukuran/Pematokan & $2.000 .000,00$ & $1.996 .000,00$ & $99,80 \%$ & $4.000,00$ & 100 \\
2 & Papan Nama Kegiatan & $300.000,00$ & $295.000,00$ & $98,33 \%$ & $5.000,00$ & 100 \\
3 & Galian Tanah & $34.550 .000,00$ & $33.950 .000,00$ & $98,26 \%$ & $600.000,00$ & 100 \\
4 & Urugan Tanah Kembali & $1.956 .000,00$ & $1.946 .000,00$ & $99,49 \%$ & $10.000,00$ & 100 \\
5 & Pasangan Batu Kali & $451.457 .890,00$ & $448.985 .000,00$ & $99,45 \%$ & $2.472 .890,00$ & 100 \\
6 & Plesteran & $115.934 .748,00$ & $116.950 .000,00$ & $100,88 \%$ & $1.015 .252,00$ & 100 \\
7 & Acian & $73.456 .000,00$ & $73.358 .000,00$ & $99,87 \%$ & $98.000,00$ & 100 \\
\hline & Pekerjaan Akhir & $650.000,00$ & $645.000,00$ & $99,23 \%$ & $5.000,00$ & 100 \\
\hline
\end{tabular}

Sumber : Dokumen Dinas PU Kabupaten Badung 2018 (sudah diolah)

Dilihat dari Tabel 2 Pengukuran rasio ekonomi pada pekerjaan irigasi Kabupaten Badung, mayoritas pekerjaan yang dilakukan pada pekerjaan irigasi Kabupaten Badung telah terjadi penghematan. Hanya ada satu pekerjaan yang tidak terjadi penghematan yaitu pada pekerjaan pekerjaan pasangan batu kali sebesar Rp. 448.985.000,00 atau sebesar 100,88\% dari anggaran sebesar 360.867.283,20. Pekerjaan ini tetap dapat dikatakan ekonomis karena realisasi sebesar Rp. 451.457.890,00 atau hanya 99,41\% dari total anggaran sebesar Rp. 680.304.638,00 dengan kata lain relisasi tidak melebihi anggaran dan dapat menghasilkan output (keluaran) mencapai 100\%. Tabel 2 juga menunjukkan bahwa galian tanah merupakan pekerjaan dengan tingkat penghemataan 
tertinggi. Dari anggaran sebesar Rp. 34.550.000,00, pekerjaan ini hanya menggunakan dana sebesar Rp. 33.950.000,00 sehingga terdapat penghematan sebesar Rp. 600.000,00 dan output (keluaran) sebesar 100\%.

2. Rasio Efesiensi Efisiensi merupakan pencapaian output yang maksimal dengan input tertentu atau penggunaan input yang rendah untuk mencapai output tertentu. Kinerja kegiatan fisik pekerjaan irigasi Kabupaten Badung dikatakan efisiensi apabila output lebih besar dari pada Input, artinya bahwa dengan dana realisasi yang digunakan bisa menghasilkan output yang lebih besar. Data output dalam penelitian ini diperoleh dari data Laporan bulanan yang terdapat di Laporan Pelaksanaan Pekerjaan Irigasi pada Dinas Perkerjaan Umum Kabupaten Badung. Nilai input didapat dari persentase dana realisasi yang digunakan untuk menghasilkan output, sedangkan nilai output didapat dari persentase pencapaian fisik pada setiap pekerjaan. Berikut ini adalah Tabel mengenai pengukuran efisiensi kegiatan fisik pekerjaan irigasi pada Dinas Pekerjaan Umum Kabupaten Badung Tahun 2018.

\section{Tabel 3. Pengukuran Rasio Efisiensi Pada Pekerjaan Irigasi Kabupaten Badung}

\begin{tabular}{c|l|r|r|r}
\hline No & \multicolumn{1}{|c|}{ Uraian } & Output (\%) & Input (\%) & $\begin{array}{c}\text { Efisiensi } \\
(\%)\end{array}$ \\
\hline 1 & Pengukuran/Pematokan & 100 & $99,80 \%$ & $99,80 \%$ \\
2 & Papan Nama Kegiatan & 100 & $98,33 \%$ & $98,33 \%$ \\
3 & Galian Tanah & 100 & $98,26 \%$ & $98,26 \%$ \\
4 & Urugan Tanah Kembali & 100 & $99,49 \%$ & $99,49 \%$ \\
5 & Pasangan Batu Kali & 100 & $99,45 \%$ & $99,45 \%$ \\
6 & Plesteran & 100 & $100,88 \%$ & $100,88 \%$ \\
7 & Acian & 100 & $99,87 \%$ & $99,87 \%$ \\
8 & Pekerjaan Akhir & 100 & $99,23 \%$ & $99,23 \%$ \\
\hline & Jumlah & 100 & $99,41 \%$ & $99,41 \%$ \\
\hline
\end{tabular}

Sumber : Dokumen Dinas PU Kabupaten Badung 2018 (sudah diolah)

Data Tabel 3 di atas tentang pengukuran rasio efisiensi pada pekerjaan irigasi Kabupaten Badung diketahui bahwa pekerjaan sudah berjalan secara efisien. Rata-rata rasio efisiensi pekerjaan ini mencapai 99,41\%, hal ini yang membuat pekerjaan irigasi Kabupaten Badung secara keseluruhan dapat dikatakan efisien. Dapat terlihat pada Tabel 
3 bahwa besanya rata-rata rasio efisiensi sebesar $99,41 \%$ dan dapat mencapai output maksimum yang pada semua pekerjaannya mencapai 100\%. Tabel 3 mengenai pengukuran efisiensi pada pekerjaan irigasi Kabupaten Badung Tahun 2018 menunjukkan nilai efisiensi tertinggi ada pada galian tanah dengan rasio efisiensi mencapai $98,26 \%$, dan nilai efisiensi terendah ada pada plesteran yaitu dengan nilai efisiensi 100,88\%. dengan output yang dihasilkan 100\%.

3. Rasio Efektivitas Pengukuran efektivitas merupakan merupakan hubungan antara keluaran (output) dengan tujuan. Efektifitas tidak menyatakan tetang beberapa besar biaya yang dikeluarkan untuk mencapai tujuan tersebut. Kinerja kegiatan fisik pekerjaan irigasi Kabupaten Badung dikatakan efektif apabila output lebih besar dari pada outcome, artinya bahwa hasil yang dicapai bisa melebihi dari tujuan atau target yang hendak dicapai. Berikut ini adalah Tabel mengenai pengukuran efektivitas kegiatan fisik pekerjaan irigasi Kabupaten Badung dari rasio efektifitas sebagai berikut:

Tabel 4. Pengukuran Rasio Efektivitas Pada Pekerjaan Irigasi Kabupaten Badung

\begin{tabular}{c|l|r|r|r}
\hline No & \multicolumn{1}{|c|}{ Uraian } & Outcome $(\boldsymbol{\%})$ & Output (\%) & $\begin{array}{c}\text { Efektivitas } \\
(\boldsymbol{\%})\end{array}$ \\
\hline 1 & Pengukuran/Pematokan & 100 & 100 & 100 \\
2 & Papan Nama Kegiatan & 100 & 100 & 100 \\
3 & Galian Tanah & 100 & 100 & 100 \\
4 & Urugan Tanah Kembali & 100 & 100 & 100 \\
5 & Pasangan Batu Kali & 100 & 100 & 100 \\
6 & Plesteran & 100 & 100 & 100 \\
7 & Acian & 100 & 100 & 100 \\
8 & Pekerjaan Akhir & 100 & 100 & 100 \\
\hline & Jumlah & 100 & 100 & 100 \\
\hline
\end{tabular}

Sumber : Dokumen Dinas PU Kabupaten Badung 2018 (sudah diolah)

Berdasarkan Tabel 4 mengenai pengukuran efektivitas pada pekerjaan irigasi Kabupaten Badung dapat diketahui bahwa semua item yang dilakukan pada pekerjaan ini dapat dikatakan efektif. Hal ini dapat terlihat dari rasio efektivitasnya yang mencapai $100,00 \%$. Artinya semua item yang dijalankan oleh seksi pengelolaan jaringan irigasi ini telah tercapai sesuai tujuan yang ditargetkan. 


\section{PEMBAHASAN}

Berdasarkan pembahasan diatas mengenai pengukuran ekonomi, efisiensi, dan efektivitas pada pekerjaan irigasi di Dinas Perkerjaan Umum Kabupaten Badung Tahun 2018, walaupun ada beberapa pekerjaan yang tidak ekonomis dan tidak efektif tetapi pada total relisasi anggaran terjadi ekonomis, efektif dan efisien, maka dapat dibuat Tabel pengukuran Pengukuran Kinerja Value For Money secara keseluruhan sebagai berikut:

Tabel 5. Pengukuran Kinerja Value For Money Pada Pekerjaan Irigasi Kabupaten Badung

\begin{tabular}{c|l|r|r|r}
\hline No & \multicolumn{1}{|c|}{ Uraian } & $\begin{array}{c}\text { Ekonomis } \\
(\boldsymbol{\%})\end{array}$ & Efisiensi (\%) & $\begin{array}{c}\text { Efektivitas } \\
(\boldsymbol{\%})\end{array}$ \\
\hline 1 & Pengukuran/Pematokan & $99,80 \%$ & $99,80 \%$ & 100 \\
\hline 2 & Papan Nama Kegiatan & $98,33 \%$ & $98,33 \%$ & 100 \\
\hline 3 & Galian Tanah & $98,26 \%$ & $98,26 \%$ & 100 \\
\hline 4 & Urugan Tanah Kembali & $99,49 \%$ & $99,49 \%$ & 100 \\
\hline 5 & Pasangan Batu Kali & $99,45 \%$ & $99,45 \%$ & 100 \\
\hline 6 & Plesteran & $100,88 \%$ & $100,88 \%$ & 100 \\
\hline 7 & Acian & $99,87 \%$ & $99,87 \%$ & 100 \\
\hline 8 & Pekerjaan Akhir & $99,23 \%$ & $99,23 \%$ & 100 \\
\hline & Total & $99,41 \%$ & $99,41 \%$ & 100 \\
\hline
\end{tabular}

Sumber : Dokumen Dinas PU Kabupaten Badung 2018 (sudah diolah)

Keterangan:

$$
\begin{aligned}
& =\text { Tidak Ekonomi } \\
& =\text { Tidak Efisiensi }
\end{aligned}
$$

Tabel 5 menujukan bahwa kegiatan fisik pekerjaan irigasi Kabupaten Badung Tahun 2018 telah mampu menjalankan tujuh pekerjaan secara ekonomis dengan ratarata rasio ekonomi kurang dari $100 \%$ dan satu pekerjaan tidak ekonomis yaitu pada pekerjaan plesteran dengan rata-rata rasio ekonomi lebih dari 100\% sesuai dengan kriteria ekonomi sebagai berikut:

Jika diperoleh nilai kurang dari 100\% berarti ekonomis 
Jika diperoleh nilai lebih dari 100\% berarti tidak ekonomis.

Secara keseluruhan kinerja kegiatan fisik irigasi Kabupaten Badung Tahun 2018 telah mampu menyelenggarakan kegiatan secara ekonomis dengan rasio ekonomi ratarata dibawah $100 \%$ atau hanya $99,41 \%$ dari total anggaran yang dianggarkan. Hal ini sesuai dengan indikator Moh. Mahsun (2006) yaitu Ekonomi artinya kehematan yang mencakup juga pengelolaan secara hati-hati atau cermat dan tidak ada pemborosan. Suatu kegiatan operasional dikatakan ekonomis jika dapat menghilangkan atau mengurangi biaya yang tidak perlu dengan kriteria jika diperoleh nilai kurang dari $100 \%$ berarti ekonomis. Hal senada diungkapkan oleh Mardiasmo (2009) bahwa, Ekonomi terkait dengan sejauh mana organisasi sektor publik dapat meminimalisir input resources dengan menghindari pengeluaran yang boros dan tidak produktif.

Tabel 5 juga menunjukan bahwa kegiatan fisik pekerjaan irigasi Kabupaten Badung Tahun 2018 telah mampu menjalankan tujuh pekerjaan secara efektif dengan rata-rata rasio efektif kurang dari $100 \%$ dan satu pekerjaan tidak efektif yaitu pada plesteran dengan rata-rata rasio efektif lebih dari 100\% sesuai dengan kriteria ekonomi menurut Moh. Mahsun (2006) sebagai berikut:

Jika diperoleh nilai kurang dari 100\% berarti efisien

Jika diperoleh nilai lebih dari 100\% berarti tidak efisien.

Secara keseluruhan kinerja kegiatan fisik irigasi Kabupaten Badung Tahun 2018 telah mampu menyelenggarakan kegiatan secara efisien dengan rasio efisien rata-rata dibawah $100 \%$ atau hanya $99,41 \%$ dari total anggaran yang dianggarkan. Hal ini sesuai dengan indikator Moh. Moh. Mahsun (2006) yaitu Efisien output tertentu dapat dicapai dengan sumber daya yang serendah-rendahnya. Suatu kegiatan operasional dikatakan efisien apabila suatu produk atau hasil kerja tertentu dapat dicapai dengan menggunakan sumber daya dan dana yang serendah-rendahnya. dengan kriteria jika diperoleh nilai kurang dari $100 \%$ berarti efisien. Hal senada diungkapkan oleh Mardiasmo (2009) bahwa, Efisiensi merupakan perbandingan output/input yang dikaitkan dengan standar 
kinerja atau target yang telah ditetapkan. Dan Indra Bastian (2006) Efisiensi adalah hubungan antara input dan output di mana barang dan jasa yang dibeli oleh organisasi digunakan untuk mencapai output tertentu.

Berdasarkan data yang ditunjukkan tabel 5 diketahui bahwa pada pekerjaan irigasi Kabupaten Badung bahwa semua pekerjaan ini dapat dikatakan efektivitas. Artinya seluruh pekerjaan dapat berjalan sesuai dengan target yang telah ditentukkan yaitu 100\%. Sesuai dengan kriteria ekonomi menurut Moh. Mahsun (2006) sebagai berikut:

Jika diperoleh nilai sama dengan 100\% berarti efektivitas.

Temuan ini senada dengan Indra Bastian (2006) yang mengemukakan bahwa Efektivitas adalah hubungan antara output dan tujuan, di mana efektivitas diukur berdasarkan seberapa jauh tingkat output, kebijakan, dan prosedur organisasi mencapai tujuan yang telah. Senada dengan Mardiasmo (2009) Jika suatu organisasi berhasil mencapai tujuannya, maka organisasi tersebut dikatakan telah berjalan efektif. Efektivitas hanya melihat apakah suatu program telah mencapai tujuan yang telah ditetapkan sebelumnya. Moh. Mahsun (2006) mengemukakan bahwa efektivitas artinya hubungan antara keluaran (output) dengan tujuan atau sasaran yang harus dicapai. Suatu kegiatan operasional dikatakan efektif apabila proses kegiatan tersebut mencapai tujuan dan sasaran akhir kebijakan.

Sejalan dengan penelitian ini Putri Ardi Ayuningtyas (2012) dalam hasil penelitian pada tempat yang berbeda tetapi sama-sama melakukan pengukuran kinerja dengan menggunakan analisis. Hasil penelitian lain dilaporkan oleh Demi Aulia Arfan (2014), yang sama melakukan pengukuran kinerja dengan menggunakan analisis Value for Money. Hal serupa yang sama dilakukan oleh Abdul Kadir (2009) melakukan pengukuran kinerja dengan menggunakan analisis Value for Money. Hasil penelitian serupa juga mendapatkan hasil yang sama dari penelitian Dwi Puwiyanti (2017). 


\section{SIMPULAN DAN SARAN}

Kesimpulan Berdasarkan hasil penelitian mengenai kinerja kegiatan fisik Pekerjaan Irigasi Kabupaten Badung dapat ditarik beberapa kesimpulan sebagai berikut:

1. Ditinjau dari rasio ekonomi, Kegiatan Fisik Pekerjaan Irigasi Kabupaten Badung tahun 2018 telah mampu menjalankan pekerjaan secara ekonomis.

2. Ditinjau dari rasio efisiensi, Kegiatan Fisik Pekerjaan Irigasi Kabupaten Badung tahun 2018 telah mampu menjalankan secara efisiens.

3. Ditinjau dari rasio efektivitas, Kegiatan Fisik Pekerjaan Irigasi Kabupaten Badung tahun 2018 telah menjalankan keseluruhan pekerjaannya dengan efektif.

Berdasarkan pembahasan dan kesimpulan dari penelitian ini dapat ditarik beberapa saran sebagai berikut:

1. Bagi Dinas Pekerjaan Umum di Kabupaten Badung.

Dinas Pekerjaan Umum di Kabupaten Badung diharapkan dalam proses membuat perencanaan anggaran (standar harga) sebaiknya melakukan survey harga pasar untuk mengetahui perbandingan antara harga pasar dan standar harga, sehingga tidak terjadi selisih yang terlalu besar antara rencana anggaran dengan realisasi anggaran.

2. Bagi Peneliti Selanjutnya

Penelitian selanjutnya diharapkan dalam penentuan outcome dapat menggunakan metode lain, misalkan menyebar angket kepada masyarakat agar diketahui kepuasan masyarakat terhadap pelayanan suatu organisasi, sehingga nilai outcome lebih riil.

\section{DAFTAR PUSTAKA}

Abdul, Halim dan Syam Kususfi. 2013. Akuntansi Sektor Publik. Jakarta: Salemba Empat.

Ardila I. dan Ayu Anindya. 2014, Analisis Kinerja Keuangan Dengan Pendekatan Value For Money pada Pengadilan Negeri Tebing Tinggi. Jurnal Riset Akutansi dan Bisnis.

Arfan, DA. 2014. Pengukuran Kinerja Dinas Pertanian Daerah Istimewa Yogyakarta Periode Tahun 2011-2012. Skripsi. Universitas Negeri Yogyakarta.

Arikunto, S. 1997. Prosedur Penelitian. Jakarta: PT. Rineka Cipta. 
Arizona, Hadi. 2010. Analisis Value For Money untuk Mengukur Kinerja Keuangan Pemerintah Kota Malang. Tesis. Universitas Brawijaya.

Ayu, Febriyanti Puspitasari. 2012. Analisis Kinerja Keuangan Pemerintah Daerah Kota Malang Tahun Anggaran 2007-2011. Jurnal. Universitas Brawijaya.

Ayuningtyas, PA. 2012. Analisis Value For Money Dalam Pengukuran Kinerja Dinas Pariwisata dan kebudayaan Kota Yogyakarta Periode Tahun 2009-2011. Tesis. Universitas Gajah Mada.

Bastian, I. 2006. Akutansi Sektor Publik: Suatu Pengantar. Jakarta: Penerbit Erlangga

Kadir, A. 2009. Implikasi Prinsip Value For Money terhadap Kinerja Satuan Kerja Perangkat Daerah (SKPD) di Kabupaten Tojo Una una. Tesis. Universitas Tadulako.

Laode, Kadafi. 2013. pengukuran Kinerja Keuangan Melalui Pendekatan Value For Money pada Badan Lingkungan Hidup Kota Tanjung Pinang. Jurnal. Universitas Maritim Raja Ali Haji Tanjungpinang.

Mahmudi. 2007. Manajemen Kinerja Sektor Publik. Edisi Revisi. Yogyakarta: UPP STIM YKPN.

Mardiasmo. 2009. Akuntansi Sektor Publik. Yogyakarta: CV. Andi Offset.

Mahsun, M. 2006. Penilaian Kinerja Sektor Publik. Edisi Pertama. Yogyakarta: BPFE. 